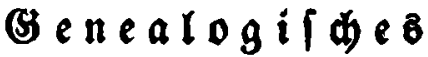

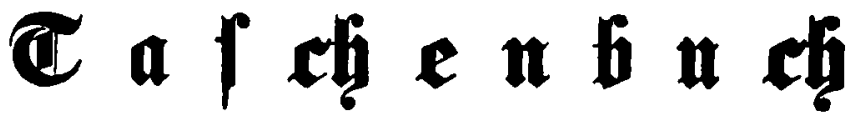

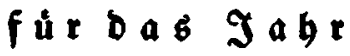

\section{6 .}

20 n

Iricorich ottschal ck.

\section{Berlin,}

b i B. $\Re$ i m r. 
